\title{
Gambaran Kinerja Perawat Pada Proses Dokumentasi Asuhan Keperawatan
}

\author{
Najla Asyah Syafawani Lubis/191101010 \\ najlaasyahsyafawani@gmail.com
}

\section{Latar Belakang}

Rumah Sakit merupakan organisasi formal pemberi pelayanan kesehatan profesional yang didalamnya terdapat visi, misi, tujuan dan struktur manajemen yang jelas serta berorientasi pada pelayanan kesehatan yang ditujukan kepada masyarakat luas. Rumah Sakit sebagai organisasi tidak dapat mengabaikan Sumber Daya Manusia (SDM) sebagai penggerak sistem dalam organisasi serta Bagaimana perilaku organisasi dari SDM itu sendiri. SDM di rumah sakit didominasi oleh perawat. Perawat sebagai tenaga kesehatan di Rumah Sakit merupakan sumber daya penting untuk ambil bagian dalam memberikan jaminan mutu layanan kesehatan. Keperawatan sebagai bentuk pelayanan profesional dilakukan oleh perawat berdasarkan standar profesi untuk memastikan pelayanan yang kompeten dan aman kepada masyarakat.

Potter dan Perry (2004) menyebutkan bahwa keperawatan memegang peran penting dalam menyediakan pelayanan kesehatan berkualitas bagi masyarakat berdasarkan standar profesi untuk dapat memberikan jaminan keamanan kepada masyarakat sebagai penerima layanan. Kualitas pelayanan keperawatan yang diberikan oleh perawat dapat diketahui melalui suatu evaluasi yaitu penilaian kinerja. Penilaian kinerja dilakukan berdasarkan prinsip dan standar profesi sehingga dapat menggambarkan hasil kegiatan perawat. Swansburg (2000) menyebutkan bahwa penilaian kinerja perawat merupakan proses kontrol kualitas pelayanan keperawatan berdasarkan standar-standar tertentu.

Penilaian kinerja perawat dapat dilihat dari hasil yang dicapai perawat dalam memberikan asuhan keperawatan, baik melalui pengamatan langsung saat proses pemberian asuhan keperawatan atau melalui dokumentasi asuhan keperawatan. Hasibuan (2003) mengemukakan perilaku perawat pelaksana dapat dilihat melalui prestasi kerja, tanggung jawab, ketaatan, kejujuran, dan kerjasama. Penelitian Gomes, F \& Proenca (2015) indikator kinerja perawat adalah variabel untuk mengukur prestasi suatu pelaksanaan kegiatan dalam waktu tertentu. Indikator yang berfokus pada hasil asuhan keperawatan kepada pasien dan proses pelayanan nya 
disebut indikator kinerja. Kinerja perawat dapat dilihat sesuai dengan peran fungsi perawat sebagai pemberi asuhan keperawatan.

Kinerja perawat dalam pelayanan keperawatan dapat dilihat dari terpenuhinya karakteristik proses keperawatan yang tergambar antara lain pada dokumentasi proses keperawatan. Dokumentasi asuhan keperawatan merupakan salah satu file yang cukup penting. Pendokumentasian ini tentu berkaitan dengan kinerja perawat dalam melaksanakan tugasnya. Ketika di lapangan, pencatatan dokumentasi menjadi identitas yang membosankan, Hal ini tertuang dalam penelitian Gugerty Brian yang menyebutkan bahwa sebagian besar responden penelitian tersebut menyatakan dokumentasi mengurangi dan langsung mempengaruhi waktu yang dihabiskan dalam memberikan perawatan pasien secara langsung padahal dokumen keperawatan juga dianggap sangat vatal dan penting.

\section{Metode}

Rancangan penugasan kajian ini menggunakan metode literatur review. Dimana metode ini dapat menyelesaikan suatu masalah dengan mengumpulkan data, menganalisa, membandingkan sehingga dapat menentukan pengambilan keputusan dalam masalah tersebut yang berdasarkan dari penjelasan sumber dan referensi yaitu berupa jurnal, ebook atau buku teks.

\section{Hasil}

Berdasarkan hasil penelitian Heriansyah, 2018. Menunjukkan bahwa kinerja perawat dalam pendokumentasian asuhan keperawatan di IRNA RSUD Ratu Zalecha Martapura dari 131 perawat pelaksana yang menjadi responden sebanyak 111 (84,7\%) mempunyai kinerja yang baik dalam pendokumentasian asuhan keperawatan. Berdasarkan hasil penelitian penatalaksanaan pengisian dokumentasi asuhan keperawatan di RSUD Tugurejo Semarang dalam kategori kurang 4 8\%, sedang 35\% dan baik 17\%. Hasil Penelitian Pribadi,2009. Menunjukkan bahwa pelaksanaan dokumentasi asuhan keperawatan di RSUD kelet Jepara dalam kategori baik 58,1\% dan tidak baik 41,9\%. Hasil Penelitian Budianto, 2012 menunjukkan kan bahwa pelaksanaan dokumentasi asuhan keperawatan di ruang rawat inap rumah sakit Islam Faisal Makassar dalam kategori baik $70 \%$, cukup baik $20 \%$ dan kurang baik $10 \%$. Pelaksanaan dokumentasi asuhan keperawatan di RSUD Ambarawa 69,1\% dalam kategori baik. 
Berdasarkan hasil penelitian Engrine Nindi, 2017. Terlihat bahwa kinerja perawat dalam pendokumentasian asuhan keperawatan di instalasi rawat inap Anggrek 2 RSUD Prof. Dr. R. D. Kandou Manado pada umumnya baik. Hal ini ditunjukkan dengan perolehan hasil bahwa kinerja perawat yang baik sebanyak $65,2 \%$ dan kinerjanya kurang baik $34,8 \%$. Penelitian yang yang sama juga dilakukan oleh Aryandini, 2015. Menemukan bahwa sebagian besar atau sebesar 83,8\% perawat di ruang rawat Instalasi Gawat Darurat Rumah Sakit PKU Muhammadiyah Yogyakarta memiliki tingkat kerja yang baik dan sisanya sebesar 16,7\% memiliki tingkat kinerja pekerja yang cukup baik dalam pendokumentasian asuhan keperawatan. Sedangkan hasil penelitian Aris Citra Wisuda, 2019. frekuensi kinerja perawat dalam pendokumentasian asuhan keperawatan, diketahui bahwa lebih dari setengah responden memiliki kinerja asuhan keperawatan dalam pendokumentasian Asuhan Keperawatan yang kurang baik yaitu sebanyak $75,0 \%$ sedangkan responden memiliki kinerja asuhan keperawatan dalam pendokumentasian Asuhan Keperawatan yang berkatagori baik yaitu sebanyak $25 \%$.

Berdasarkan hasil analisis penelitian Intan Diah Pramithasari,2016. Didapatkan persentase nilai pendokumentasian pengkajian keperawatan sebesar 83\%. Apabila dibandingkan dengan standar minimal pelayanan rumah sakit, maka dapat disimpulkan bahwa kinerja perawat dalam mendokumentasikan pengkajian keperawatan di RSUD Banyumas masih dalam kategori kurang. Berdasarkan data penelitian mursidah Dewi, 2014. Yang berhubungan dengan pelaksanaan pendokumentasian proses asuhan keperawatan di ruang rawat inap Rumah Sakit Dr. Hanifie Muaro Bungo yang diperoleh dari bidang keperawatan tercatat rata-rata angka ketidaklengkapan dokumentasi asuhan keperawatan yaitu dokumentasi pengkajian 71, 22\%, dokumentasi diagnosa keperawatan 89,74\%, dokumentasi perencanaan 83,31\%, dokumentasi implementasi 58,8\%, evaluasi 78,09\% dan dokumentasi catatan pengembangan 77,34\%. Hasil Penelitian - penelitian tersebut menggambarkan bahwa kepatuhan serta Kinerja perawat dalam dokumentasi asuhan keperawatan masih sangat bervariasi.

\section{Pembahasan}

Kinerja perawat pelaksana dalam pelaksanaan asuhan keperawatan merupakan upaya meningkatkan mutu pelayanan keperawatan yang diberikan dalam bentuk kinerja perawat dan harus didasari kemampuan yang tinggi sehingga kinerja mendukung pelaksanaan tugas dalam pelayanan keperawatan. Kinerja merupakan suatu hasil kerja seseorang yang dilakukan sesuai 
dengan tugas dalam suatu organisasi (Nursalam, 2015). Sedangkan menurut Effendy, 2015. Kinerja perawat yang baik merupakan jembatan dalam menjawab jaminan kualitas pelayanan kesehatan yang diberikan terhadap pasien baik yang sakit maupun yang sehat. Kunci utama dalam peningkatan kualitas pelayanan kesehatan adalah perawatan yang mengenai kinerja tinggi. Perilaku kerja atau performance yang dihasilkan perawat tidak lepas dari faktor yang mempengaruhinya (Wisuda, 2019).

Kinerja perawat dalam memberikan pelayanan asuhan keperawatan yaitu pengkajian, diagnosis, perencanaan, implementasi dan evaluasi sudah mencapai standar yang telah ditetapkan oleh Depkes RI. Standar praktik keperawatan profesional merupakan pedoman bagi perawat di Indonesia dalam melaksanakan Asuhan Keperawatan dengan menggunakan pendekatan proses keperawatan. Standar praktik tersebut dilaksanakan oleh perawat generalis maupun spesialis di seluruh tatanan pelayanan kesehatan di Rumah Sakit maupun tatanan pelayanan lain di masyarakat. Standar dokumentasi asuhan keperawatan mengacu pada proses keperawatan yang terdiri dari 5 tahap yaitu pengkajian, diagnosis, perencanaan, implementasi dan evaluasi (Nursalam, 2011).

Kinerja perawat dalam pelayanan keperawatan dapat dilihat dari terpenuhinya karakteristik proses keperawatan yang tergambar antara lain pada dokumentasi proses keperawatan. penilaian kinerja perawat melalui dokumentasi dapat di lakukan penilaian secara objektif dengan metode penerapan dan Instrumen penilaian yang baku instrumen evaluasi penerapan standar Asuhan Keperawatan yang terdiri dari : pertama instrumen studi dokumentasi penerapan standar Asuhan Keperawatan yang disebut instrumen A, yang kedua instrumen evaluasi persepsi pasien terhadap mutu asuhan keperawatan di rumah sakit yang disebut instrumen $\mathrm{B}$, yang ketiga instrumen observasi pelaksanaan tindakan keperawatan di rumah sakit yang disebut instrumen C (DepKes, 2001).

Dokumentasi merupakan salah satu komponen penting yang dapat memberikan kesaksian hukum, dan bisa menjadi alat komunikasi dan sumber edukasi serta sumber reset. Pendokumentasian asuhan keperawatan secara akurat dan berkesinambungan diatur dalam peraturan Menteri Kesehatan Nomor 148 tahun 2010 tentang izin dan penyelenggaraan praktik perawat, dalam pasal 12 ayat 1 (PERMENKES,2015). 
Dokumentasi keperawatan sangat penting bagi perawat, dokumentasi adalah bagian dari keseluruhan tanggung jawab perawat untuk perawatan pasien. Catatan klinis memfasilitasi keseluruhan pelayanan yang diberikan pada pasien dan membantu mengkoordinasikan pengobatan dan evaluasi pasien (Patricia, 2004). Dokumentasi proses asuhan keperawatan merupakan tampilan perilaku atau kinerja perawat pelaksana dalam memberikan proses asuhan keperawatan kepada pasien selama pasien dirawat di rumah sakit. Dokumentasi keperawatan merupakan catatan otentik dalam penerapan manajemen asuhan keperawatan profesional. Komponen penting dalam pendokumentasian adalah komunikasi, proses keperawatan dan standar asuhan keperawatan. Efektivitas dan efisiensi sangat bermanfaat dalam mengumpulkan informasi yang relevan serta akan meningkatkan kualitas standar dokumentasi keperawatan (Nursalam, 2014).

Kualitas pendokumentasian keperawatan dapat dilihat dari kelengkapan dan keakuratan menuliskan proses Asuhan Keperawatan yang diberikan kepada pasien. Sitorus (2006) menguraikan proses keperawatan merupakan metode yang sistematis dalam memberikan Asuhan Keperawatan, yang terdiri atas lima langkah, yaitu pengkajian, diagnosis keperawatan, perencanaan pelaksanaan dan evaluasi yang perlu didokumentasikan secara lengkap. Dampak ketidaklengkapan dokumentasi asuhan keperawatan dapat mengundang permasalahan hukum terutama bila perawat melakukan kesalahan maupun kelalaian yang menimbulkan kerugian bagi pasien. Dokumentasi yang tidak lengkap juga dapat menyebabkan Asuhan Keperawatan yang dilakukan tidak komprehensif, asuhan keperawatan menjadi putus-putus, terjadi pengulangan tugas-tugas baik yang bersifat keperawatan langsung maupun tidak langsung, melambatnya pemulihan dan secara tidak langsung dapat menimbulkan komplikasi yang seharusnya dapat dihindari (Perry dan Potter, 2005). Tidak adanya kontrol pendokumentasian yang benar juga dapat berdampak pada pelayanan yang diberikan kepada pasien akan cenderung kurang baik dan dapat merugikan pasien.

Kepatuhan dokumentasi asuhan keperawatan belum optimal pada item diagnosis keperawatan, perencanaan keperawatan dan evaluasi. Beberapa diagnosis keperawatan juga tidak mencerminkan PE/PES, dan masalah yang telah dirumuskan titik perencanaan disusun tidak berdasarkan prioritas, tidak mengacu pada tujuan dengan kalimat perintah terinci dan jelas dan serta tidak menggambarkan ketertiban pasien atau keluarganya. Evaluasi masih belum mengacu 
pada tujuan dan masih ada perawat yang tidak mengisi paraf pada lembar dokumentasi asuhan keperawatan (Putra, 2016).

Ketidakpatuhan perawat dalam mendokumentasikan asuhan keperawatan bisa mengakibatkan malpraktek dan duplikasi tindakan keperawatan yang dilakukan. Menurut konsep asuhan keperawatan Salah satu tujuan pendokumentasian adalah sebagai alat komunikasi, mekanisme gugatan dan sebagai audit pelayanan keperawatan. semakin banyak perawat yang tidak patuh mendokumentasikan asuhan keperawatan maka akan semakin tinggi resiko terjadinya kesalahan dalam pemberian asuhan keperawatan, semakin kurang bukti tanggung jawaban dan tanggung gugat perawat (Wisuda, 2019).

Beberapa hambatan yang berhubungan dengan pendokumentasian asuhan keperawatan menurut Depkes RI (2008) yaitu kekurangannya pemahaman dasar-dasar dokumentasi keperawatan. Hal ini bisa terjadi karena latar belakang pendidikan yang berbeda-beda, sehingga tidak adanya keseragaman pelaksanaan dokumentasi keperawatan. Kurangnya kesadaran akan pentingnya dokumentasi keperawatan. penulisan dokumentasi keperawatan tidak mengacu pada standar yang sudah ditetapkan, sehingga terkadang tidak lengkap dan tidak akurat. Dokumentasi keperawatan dianggap beban. Banyaknya lembar format yang harus diisi untuk mencatat data dan intervensi keperawatan pada pasien membuat perawat terbebani. Keterbatasan tenaga. Kurangnya tenaga perawat yang ada dalam suatu tatanan pelayanan kesehatan memungkinkan perawat bekerja hanya berorientasi pada tindakan saja. Tidak cukup waktu untuk menuliskan Setiap tindakan yang telah diberikan pada lembar format dokumentasi keperawatan. Ketiadaan pengadaan lembar format dokumentasi keperawatan oleh institusi titik tidak semua tindakan keperawatan yang diberikan kepada pasien dapat didokumentasikan dengan baik. Karena lembar format yang ada tidak menyediakan tempat (kolom untuk menuliskannya) ( Wirawan, 2013).

Perilaku pendokumentasian asuhan keperawatan dipengaruhi oleh faktor internal dari perawat itu sendiri. Faktor internal tersebut dapat diakibatkan dengan sikap perawat, kebiasaan atau perilaku yang ada selama bekerja, Adapun faktor eksternal yang ada dapat diakibatkan oleh jumlah peralatan atau sarana, perbandingan tenaga perawat pelaksana dan pasien, Sehingga dalam pelaksanaan pendokumentasian asuhan keperawatan diperlukan pengawasan dan bimbingan dalam bentuk supervisi. Supervisi kepala ruangan diperlukan terhadap pelaksanaan 
pendokumentasian asuhan keperawatan untuk menjamin bahwa pendokumentasian asuhan keperawatan berjalan sesuai dengan prinsip-prinsip utama pendokumentasian (Wirawan, 2013).

\section{Kesimpulan}

Setiap pelaksanaan proses keperawatan, Perawat akan selalu melakukan pencatatan atau sering disebut pendokumentasian, mulai dari pengkajian, diagnosis, perencanaan, pelaksanaan, dan evaluasi. Dokumentasi merupakan aspek penting dari praktik keperawatan Karena berisi catatancatatan yang berguna untuk komunikasi, tagihan financial, edukasi, pengkajian, riset, audit dan dokumentasi legal, dokumentasi didefinisi sebagai segala sesuatu yang tertulis atau tercetak yang dapat diandalkan sebagai catatan tentang bukti bagi individu yang berwenang, dokumentasi yang baik mencerminkan tidak hanya berkualitas perawatan tapi juga membuktikan pertanggunggugatan setiap anggota tim perawat dalam memberikan perawatan. Kinerja perawat merupakan pencapaian atau prestasi seseorang berkenaan dengan seluruh tugas yang diberikan kepadanya sesuai dengan standar yang berlaku. Berdasarkan dari hasil penelitian-penelitian tersebut didapatkan bahwa kinerja perawat dalam proses pendokumentasian asuhan keperawatan masih belum optimal dan perlu perbaikan lagi.

\section{Daftar Pustaka}

Dewi, M., \& Zesti, R. (2014). Hubungan Kepemimpinan Dan Supervisi Deangan Kinerja Perawat Pelaksana Dalam Pendokumentasian Asuhan Keperawatan. Jurnal Managemen Keperawatan, 2 (1), 13-21.

Heriyansyah., Pertiwiwati, E., \& Rizany, I. (2018). Tanggung Jawab Pelaksana Metode Tim Dengan Kinerja Perawat Dalam Pendokumentasian Asuhan Keperawatan Di IRNA RSUD Zalecha Martapura. Nerspedia, 1 (1), 147-155.

Mastini, P., Suryadhi, N, T., \& Suryani, A. (2015). Hubungan Tingkat Pengetahuan, Sikap, Beban Kerja Perawat dengan Kelengkapan Dokumentasi Asuhan Keperawatan di IRNA IGD RSUP Sanglah Denpasar. Public Health and Preventive Medicine Archive, 3 (1), 49-53.

Nindi, E., Mendur, F., \& Marentek, D, L. (2017). Hubungan Pelaksanaan Timbang Terima DEngan Kinerja Perawat Di Pelaksana Dalam Pendokumentasian Asuhan Keperawatan Di 
Instalasi Rwat Inap Anggrek 2 RSUP Prof DR. R. D. Kandou Manado. Journal Of Community \& Emergency, 5 (3), 66-76.

Putra, A, A., Rejeki, S., \& Kristina, T, N. (2016). Hubungan Persepsi Perawat Tentang Karakteristik Pekerjaan Dengan Kepatuhan Dalam Pendokumentasian Asuhan Keperawatan. Jurnal Keperawatan Notokusumo, 4 (1), 1-11.

Pramithasari, I, D. (2016). Gambaran Kinerja Perawat Dalam Mendokumentasikan Asuhan Keperawatan Berbasis Komputer Di RSUD Banyumas. Jurnal Keperawatan Muhammadiyah, $1(1), 40-47$.

Simamora, R. (2009). Dokumentasi Proses Keperawatan.

Simamora, R. H., Purba, J. M., Bukit, E. K., \& Nurbaiti, N. (2019). Penguatan Peran Perawat Dalam Pelaksanaan Asuhan Keperawatan Melalui Pelatihan Layanan Prima. JPPM (Jurnal Pengabdian Dan Pemberdayaan Masyarakat), 3(1), 25-31.

Siswanto, L, M., Hariyati, R, T., \& Sukihananto. (2013). Faktor-Faktor Yang Berhubungan Dengan Kelengkapan Pendokumentasian Asuhan Keperawatan. Jurnal Keperawatan Indonesia, $16(2), 77-84$.

Widodo, W, N., Wungow, H., \& Hamel, R, S. (2016). Hubungan Peran Ketua Tim Dengan Kinerja Perawat Pelaksana Dalam Pendokumentasian asuhan Keperawatn Di Irina F RSUP Prof DR.R.D. Kandou Manado. E-Journal Keperawatan, 4 (2), 1-5.

Wirawan, A, E., Novitasari, D., \& Wijayanti, F. (2013). Hubungan Antara Supervisi Kepala Ruang Dengan Pendokumentasian Asuhan Keperawatan Di Rumah Sakit Umum Daerah Ambarawa. Jurnal Managemen Keperawatan, 1 (1), 1-6.

Wisuda, A, C., \& Putri, D, O. (2019). Kinerja Perawat Pelaksana Dalam Pendokumentasian Asuhan Keperawatan Di Instalasi Rawat Inap. Jurnal Aisiyah Medika, 4 (2), 230-238. 